\begin{tabular}{c|l|l|l}
$\begin{array}{c}\text { Case Reports in } \\
\text { Oncology }\end{array}$ & $\begin{array}{l}\text { Case Rep Oncol 2010;3:368-371 } \\
\text { DOl: 10.1159/000321630 }\end{array}$ & $\begin{array}{l}\text { Published online: } \\
\text { October 12, 2010 }\end{array}$ & $\begin{array}{l}\text { O 2010 S. Karger AG, Basel } \\
\text { ISS 1662-6575 } \\
\text { www.karger.com/cro }\end{array}$ \\
\hline
\end{tabular}

\title{
Favorable Clinical Course of Patients Experiencing Bevacizumab-Induced Proteinuria
}

\author{
Emmanouil Saloustros Nikolaos Androulakis \\ Lambros Vamvakas Dimitris Mavroudis \\ Vassilis Georgoulias \\ Department of Medical Oncology, University General Hospital of Heraklion, \\ Heraklion, Greece
}

\section{Key Words}

Bevacizumab · Proteinuria $\cdot$ Response

\begin{abstract}
Nephrotic-range proteinuria, which denotes structural damage to the glomerular filtration barrier, occurs in $1-2 \%$ of bevacizumab-treated patients. The glomerular injury and subsequent proteinuria is probably due to a direct targeting of vascular endothelial growth factor (VEGF). We report a case series of six patients who developed a syndrome characterized by proteinuria and hypertension after starting therapy with bevacizumab and who experienced prolonged progression-free survival. Given that altered glomerular permeability appears to be a direct consequence of VEGF inhibition, we hypothesize that proteinuria may indeed correlate with drug efficacy. Optimizing safe and effective drug dosing is critical to achieve the best therapeutic impact due to limited treatment options for many life-threatening advanced cancers. Clinicians should be aware that the development of proteinuria might serve as a surrogate marker of bevacizumab antitumor efficacy and determine the appropriate criteria for withholding this effective anticancer therapy.
\end{abstract}

\section{Introduction}

The humanized monoclonal antibody bevacizumab (Avastin ${ }^{\circledR}$ Genentech/Roche) is increasingly used to treat malignant solid tumors. This antibody recognizes and blocks vascular endothelial growth factor (VEGF)-A [1]. The latter is a chemical signal that stimulates the growth of new blood vessels (angiogenesis). In the kidney, glomerular podocytes express VEGF and glomerular endothelial cells express VEGF receptors. 
Podocyte-specific deletion of a single VEGF allele causes proteinuria and capillary endotheliosis in rodents, and disrupted glomerular VEGF signaling is strongly implicated in the pathogenesis of human preeclampsia, a syndrome characterized by proteinuria and hypertension [2-4].

\section{Case Presentation}

In the institutional review case series described here, six patients developed a syndrome characterized by proteinuria and hypertension after starting therapy with bevacizumab. History of patients before commencing treatment, was unremarkable for hypertension and kidney disease, while urinalysis was normal. Patients were identified clinically after developing edema, hypertension, proteinuria, and/or hypoalbuminemia (table 1). All six patients developed proteinuria grade 2 (2-3+ protein in dipstick urinalysis or 1.0-3.5 g in 24-hour urine for protein) or higher, and new or exacerbated hypertension required on average two antihypertensive medications. Glomerulonephritis and microangiopathic hemolytic anemia were excluded based on the results of blood and urine sediment tests. In most patients, the bevacizumab dose was either reduced or discontinued. Subsequently, in patients with follow-up information, there was a dramatic improvement (patients 1,2, $3,5)$ of proteinuria.

Since 2003, at least 481 patients have been treated with bevacizumab at our institution; thus, the cumulative crude incidence of renal adverse events is $1.2 \%$. However, the true prevalence of bevacizumab-associated renal toxicity is likely higher because patients were not routinely screened in a systematic, prospective, and long-term manner for the development of new proteinuria.

Interestingly, all patients experienced prolonged progression-free survival, defined as the time interval from treatment initiation to documented progression or death. With the exception of one of the patients, who received paclitaxel and bevacizumab as first-line treatment for metastatic breast cancer, all other patients received the antibody in combination with various agents as fourth- or fifth-line treatment. Progression-free survival of more than 16 months for taxane/anthracycline refractory metastatic breast cancer, or of more than 6 months for a heavily pre-treated patient with metastatic non-small cell lung cancer, compared favorably to reported trials of such patient populations $[5,6]$. Even the patient with small cell lung cancer died as a result of septic shock secondary to infection, without evidence of disease progression.

\section{Discussion}

Nephrotic-range proteinuria, which denotes structural damage to the glomerular filtration barrier, occurs in 1-2\% of bevacizumab-treated patients [7]. Although several potential causes of this type of proteinuria have been suggested $[8,9]$, it is difficult to distinguish the general effects of therapy, such as an immunologic response to the monoclonal antibody, from the direct effects due to inhibition of endogenous VEGF signaling in non-cancerous tissues. Recently, it was shown that local reduction of VEGF within the kidney was sufficient to trigger the pathogenesis of thrombotic microangiopathy by the use of a conditional gene targeting to delete VEGF from renal podocytes in adult mice. This resulted in a profound thrombotic glomerular injury, providing evidence that the glomerular injury of patients treated with bevacizumab is probably due to a direct targeting of VEGF by the antiangiogenic therapy [10].

Given that the altered glomerular permeability appears to be a direct consequence of VEGF inhibition, proteinuria may indeed correlate with drug efficacy [10]. Interestingly, hypertension, which represents another vascular toxicity of bevacizumab, has already been proposed as a predictive marker for antiangiogenic treatment efficacy [11]. 
Whether the development of proteinuria might also serve as a surrogate marker of antitumor efficacy is unknown. This could be proven only in the context of a clinical trial designed specifically to address this question. However, a large number of patients should be enrolled in such a study due to the relative low incidence of grade 2 or higher proteinuria [7]. In addition, the recent FDA Oncologic Drugs Advisory Committee's vote in favor of removing the metastatic breast cancer indication from the drug labeling makes the design of such a trial highly unlikely.

On the other hand, treatment options for these life-threatening advanced cancers are limited, and optimizing safe and effective drug dosing may be critical to achieve the best therapeutic impact. Clinicians should be aware of the hypothesis that individuals experiencing bevacizumab-induced proteinuria potentially represent a group of patients who derive a great benefit from anti-angiogenic treatment and consider the pros and cons before withholding this effective anticancer therapy.

Table 1. Summary of patients who experienced prolonged disease-free survival and bevacizumabinduced proteinuria

\begin{tabular}{|c|c|c|c|c|c|c|c|c|}
\hline No. & $\begin{array}{l}\text { Age/ } \\
\text { gender }\end{array}$ & Cancer & $\begin{array}{l}\text { Line } \\
\text { of treat- } \\
\text { ment }\end{array}$ & $\begin{array}{l}\text { Regimen } \\
\text { (+bevacizumab) }\end{array}$ & $\begin{array}{l}\text { Worsening/ } \\
\text { new onset } \\
\text { HTN }\end{array}$ & $\begin{array}{l}\text { Grade } \\
\text { of pro- } \\
\text { teinuria }\end{array}$ & $\begin{array}{l}\text { Res- } \\
\text { ponse }\end{array}$ & $\begin{array}{l}\text { PFS } \\
(\mathrm{mo})\end{array}$ \\
\hline 1 & $60 / \mathrm{F}$ & Breast & 4 & Letrozole & yes & 2 & SD & $16+$ \\
\hline 2 & $76 / \mathrm{M}$ & NSCLC & 5 & Pemetrexed & yes & 2 & $\mathrm{SD}$ & $6+$ \\
\hline 3 & $75 / \mathrm{F}$ & Breast & 1 & Paclitaxel & yes & 2 & $\mathrm{CR}$ & $9+$ \\
\hline 4 & $49 / \mathrm{F}$ & Breast & 5 & Lapatinib & yes & 2 & SD & 6 \\
\hline 5 & $65 / \mathrm{F}$ & Breast & 4 & Vinorelbine & yes & 2 & SD & $13+$ \\
\hline 6 & $70 / \mathrm{M}$ & SCLC & 4 & Paclitaxel & yes & 4 & SD & 3 \\
\hline
\end{tabular}

HTN = Hypertension; PFS = progression-free survival; NSCLC $=$ non-small cell lung cancer; $\mathrm{SCLC}=$ small cell lung cancer; $\mathrm{SD}=$ stable disease; $\mathrm{CR}=$ complete remission; $\mathrm{mo}=$ months.

\section{References}

1 Los M, Roodhart JM, Voest EE: Target practice: lessons from phase III trials with bevacizumab and vatalanib in the treatment of advanced colorectal cancer. Oncologist 2007;12:443-450.

-2 Eremina V, Sood M, Haigh J, Nagy A, Lajoie G, Ferrara N, Gerber HP, Kikkawa Y, Miner JH, Quaggin SE: Glomerular specific alterations of VEGF - A expression lead to distinct congenital and acquired renal diseases. J Clin Invest 2003;111:707-716.

-3 Maynard SE, Min JY, Merchan J, Lim KH, Li J, Mondal S, Libermann TA, Morgan JP, Sellke FW, Stillman IE, Epstein FH, Sukhatme VP, Karumanchi SA: Excess placental soluble fms-like tyrosine kinase 1 (sFlt1) may contribute to endothelial dysfunction, hypertension, and proteinuria in preeclampsia. J Clin Invest 2003;111:649-658.

4 Maynard S, Epstein FH, Karumanchi SA: Preeclampsia and angiogenic imbalance. Annu Rev Med 2008;59:6178.

5 Fumoleau P, Largillier R, Clippe C, Dièras V, Orfeuvre H, Lesimple T, Culine S, Audhuy B, Serin D, Curé H, Vuillemin E, Morère JF, Montestruc F, Mouri Z, Namer M: Multicentre, phase II study evaluating capecitabine 
monotherapy in patients with anthracycline- and taxane-pretreated metastatic breast cancer. Eur J Cancer 2004;40:536-542.

-6 Hanna N, Shepherd FA, Fossella FV, Pereira JR, De Marinis F, von Pawel J, Gatzemeier U, Tsao TC, Pless M, Muller T, Lim HL, Desch C, Szondy K, Gervais R, Shaharyar, Manegold C, Paul S, Paoletti P, Einhorn L, Bunn PA Jr: Randomized phase III trial of pemetrexed versus docetaxel in patients with non-small-cell lung cancer previously treated with chemotherapy. J Clin Oncol 2004;22:1589-1597.

7 Zhu X, Wu S, Dahut WL, Parikh CR: Risks of proteinuria and hypertension with bevacizumab, an antibody against vascular endothelial growth factor: systematic review and meta-analysis. Am J Kidney Dis 2007;49:186193.

-8 Gerber HP, Wu X, Yu L, Liang XH, Lee CV, Fuh G, Olsson C, Damico L, Xie D, Meng YG, Gutierrez J, Corpuz R, Li B, Hall L, Rangell L, Ferrando R, Lowman H, Peale F, Ferrara N: Mice expressing a humanized form of VEGF-A may provide insights into the safety and efficacy of anti-VEGF antibodies. Proc Natl Acad Sci USA 2007;104:3478-3483.

9 George BA, Zhou XJ, Toto R: Nephrotic syndrome after bevacizumab: case report and literature review. Am J Kidney Dis 2007;49:e23-e29.

10 Eremina V, Jefferson JA, Kowalewska J, Hochster H, Haas M, Weisstuch J, Richardson C, Kopp JB, Kabir MG, Backx PH, Gerber HP, Ferrara N, Barisoni L, Alpers CE, Quaggin SE: VEGF inhibition and renal thrombotic microangiopathy. N Eng J Med 2008;358:1129-1136.

-11 Scartozzi M, Galizia E, Chiorrini S, Giampieri R, Berardi R, Pierantoni C, Cascinu S: Arterial hypertension correlates with clinical outcome in colorectal cancer patients treated with first-line bevacizumab. Ann Oncol 2009;20:227-230. 